\title{
Women on The Text According To Amina Wadud Muhsin in Qur'an and Women
}

\author{
Abu Bakar \\ (Ushuluddin and Philosophy Faculty, UIN Sunan Ampel Surabaya \\ Jl. A. Yani No. 117 Surabaya, Email:abubakaryamani@yahoo.com)
}

\begin{abstract}
:
This article explains hermeneutic concept of Amina Wadud stating that men and women are equal. It is based on the interpretation of both Qur'anic keywords (nafs, min and azwaj) and Qur'anic concepts (qiwamah, angel and nusyuz). Wadud reasoned that those key words and concepts were, unfortunately, red partially by most of commentators and resulted gender biased exegetical works. Using the method of descriptive and critical, this article aims to elaborate how Wadud argued against the pathriarcal exegesis of the Qur'an in her book, Qur'an and Women. At the conclusion, it is found that Wadud criticized the biased works using two steps of hermeneutical approach. The first is by examining on how The Qur'an mentions some relating issues and second is by creating generalization on special respons about historical background.
\end{abstract}

\section{Keywords:}

Patriarchal exegesis, hermeneutics, equality, justice

\begin{abstract}
Abstrak:
Artikel ini menjelaskan konsep hermeneutika Amina Wadud perihal kesetaraan laki-laki dan perempuan. Konsep ini berdasarkan penafsiran Wadud terhadap beberapa kata kunci (nafs, min dan azwaj) dan konsep kunci (qiwamah, angel dan nusyuz) dalam Al-Qur'an yang, menurutnya, ditafsiri parsial oleh sebagian besar mufassir sehingga melahirkan tafsir yang bias gender. Dengan menggunakan metode deskriptif dan kritis, artikel ini berupaya menguraikan bagaimana dengan argumen-argumennya dalam buku berjudul Qur'an and Women, Wadud melawan penafsiran patriarki. Dapat disimpulkan bahwa Wadud melakukan kerja hermeneutiknya dengan dua langkah. Pertama adalah memerhatikan bagaimana Al-Qur'an menyinggung beberapa isu
\end{abstract}

al-1hkâm Vol.13 No.1 Juni 2018

DOI 10.19105/al-ihkam.v13i1.1467 
Abu Bakar

terkait dan kedua adalah merumuskan generalisasi perihal responrespon khusus Al-Qur'an terhadap peristiwa-peristiwa tertentu.

Kata kunci:

Tafsir Patriarki, Hermeneutika, Kesetaraaan, Keadilan

\section{Introduction}

Contemporary Moslem thinkers, either men such as Nasr Hamd Abu Zayd, ${ }^{1}$ Asghar Ali Engineer ${ }^{2}$ and Syahrur ${ }^{3}$ or women such as Fatimah Mernissi, ${ }^{4}$ Riffat Hassan ${ }^{5}$ and Amina Wadud Muhsin ${ }^{6}$ firmly argue that Islam is a religion without discrimination. What makes Islam look as if 'discriminating' two sexes is the exegesis of The Qur'an which is based on the tradition of humiliation to women. In other words, they assume that the tradition plays a significant role in determining the pattern on how to understand both the Holy Qur'an and other religious texts such as hadith.

The tradition can be well traced back to the old scholars who, in stating any idea, ignored the condition around the text. The exegetical works or traditional books discussing about women witnesses, hereditary portion, numbers of animal for aqiqah, the right to propose divorce and other cases put women in a position with half value than men. Regarding with this, Masdar F. Mas'udi made a systematic elaboration that in fact, women experience two types of humiliation. First, they are considered as a half in value less than men

1 The idea of Abu Zayd about women is, among others, accessible at Nasr Hamd Abu Zayd, Dawâir al-Khawf: Qirâ'ah 'alâ Khitâbi al-Mar'ah, 3rd edition. (Beirut: Dâr alBaydla', 2004).

2 The idea of Engineer about women is, among others, accessible at The Right of Women in Islam (Lahore: Vanguard Books (PVT) LTD, 1992).

3 The idea of Syahrur about women is, among others, accessible at Dirâsâtu Islâmiyah Mu'ashirah, Nahwwa Ushûli al-Jadîdah li al-Fiqhi al-Islâmî (Damaskus: al-Ahâli, 1990).

4 The idea of Mernissi about women is, among others, accessible at The Veil and the Male Elite: A Feminist Interpretation of Women's Rights in Islam, translated by Mary Jo Lakeland (New York: Basic, 1991).

5 The idea of Riffat Hasan about women is, among others, accessible at Women's and Men's Liberation (New York: Greenwood Press, 1991).

6 The idea of Wadud about women is, among others, accessible at Qur'an and Women (Kuala Lumpur: Fajar Bakti Sdn Bdn, 1994). 
and second, they become the object with the men serving as the subject.

For the former category, considering some old traditional books such as al-Iqnâ' of Syarbini, Fathu al-Wahhâb of Zakariyâ alAnshârî and al-Bâjûrî of al-Bâjûrî, Masdar mentioned five related things. First, in 'aqîah (celebration after a baby was born), baby boy's parent is recommended to slaught two (2) sheeps, while baby girl is only one (1) sheep. Second, a murder of a man needs to pay diyat (punishment to the killer) at maximum 100 (one hundred) camels. Meanwhile, a murder of a woman only needs to pay the half, which is 50 (fifty) camels. Third, in being a witness in the court, a man could do that right away, yet a woman needs another woman to support her. Fourth, in hereditary portion, men get two portions, while women only one. Fifth, men deserve to marry more than a woman, while women do not. ${ }^{7}$

As for the latter, Masdar subcategorized it into six types. First, a man has a right to marry with, while a woman is married to. Second, before marriage, a man is allowed to see some parts of a woman's body, while a woman does not do so. Third, as men are the subject of marriage, they also become the subject in divorce. Women, at maximum, could submit unfaithful motion to the judge. Only when it is accepted and considered reasonably, the judge would instruct the husband for divorce. Furthermore, the process of khulu' (when a wife pays some money to strive for divorce) will run well only when the husband wills. Fourth, a husband has exclusive right for asking her wife not to do uncompulsary fasting or to always available for sexual relationship while a wife does not. Fifth, a husband could give-or not to give-permission for his wife to go out from home, including when her parents pass away. ${ }^{8}$

Here is the urgency to discuss Wadud's argument as she compiled intellectualism and activism. At first, she made significant reconstruction on the understanding of the sources of Islamic teaching. Later, she continued by doing a real action when appointing

7 Masdar F. Mas'udi, "Perempuan di Antara Lembaran Kitab Kuning", in Mansour Fakih, dkk, Membincang Feminisme, Diskursus Gender dalam Perspektif Islam (Surabaya: Risalah Gusti, 2000), 170-171.

8 Ibid., 172-173. 
herself as an imam at the Jumu'ah prayer on March 18, 2005. This does distinguishes herself from other women thinkers such as Riffat Hasan and Fatimah Mernissi.

Furthermore, the writings about Wadud and her work mostly elaborate both her argument and methodology. The writing of Asna Andirani, ${ }^{9}$ Ernita Dewi, ${ }^{10}$ Mutrofin, ${ }^{11}$ Irsyadunnas, ${ }^{12}$ dan Nor Saidah ${ }^{13}$ are some to mention. In addition to both aspects, this writing would like to open a broader horizon on the discussion of women. It is known that in the last 2017, violence against women are still high in number. Indonesian National Commission of Women mentioned about 259.000 cases with the most of it, about 255.000, comes from personal sphere. It consisted of physical, physchological, sexual and economic one. ${ }^{14}$ Realized or not, the practice of violence has a close relation to the pathriarcal system of society and religously legitimized paradigm. Therefore, criticism on those two causes is urgent to present.

This writing is also wished to cognitively contribute in putting women in a more respective and honorable position. To achieve that, the research questions of this are, first, how the method of Wadud in reconstructing the biased exegetical works in her book, Qur'an and Women, is ${ }^{15}$ and second, how the reconstruction could be applied in the real life. The method of this writing is descriptive and critical. Descriptive means to describe and expose Wadud's argument on women in Qur'an and Women. Meanwhile, critical means to critically

9 Asna Andiani, “Konsep Penciptaan Perempuan: Studi Atas Pemikiran Amina Wadud dalam Buku Qur'an And Woman", in Kontemplasi, Vol. 01 Number 02 (November 2013), 300-315

10 Ernita Dewi, "Pemikiran Amina Wadud Tentang Rekonstruksi Penafsiran Berbasis Metode Hermeneutik" in Substantia, Vol. 15, No. 2 (October 2013), 145-167.

11 Mutrofin, "Kesetaraan Gender dalam Pandangan Amina Wadud dan Riffat Hasan" on Teosofi: Jurnal Tasawuf dan Pemikiran Islam, Vol. 3 Number 1 June 2013, 235-266.

12 Irsyadunnas, "Tafsir Ayat-Ayat Gender Ala Amina Wadud Perspektif Hermeneutika Gadamer" in Musâwa, Vol. 14, Number 2 (July 2015), 123-140.

13 Nor Saidah, “Bidadari dalam Konstruksi Tafsir al-Qur'an: Analisis Gender atas Pemikiran Amina Wadud Muhsin dalam Penafsiran al-Qur'an" in PALASTREN, Vol. 6, Number 2 (December 2013), 441-472

14https://www.komnasperempuan.go.id/file/pdf_file/2017\%20Siaran\%20Pers/Lem bar\%20Fakta\%20Catahu\%202017.pdf. Accessed on February 28, 2018.

15 Amina Wadud Muhsin, Qur'an and Women, (Kuala Lumpur: Fajar Bakti Sdn Bdn, 1994). 
analyze the argument in relation to current condition of women. Additionally, this writing aims to arise two things, which are the decreasing number of discrimination and violence against women in the name of religion and the rise of new awareness for women to change the condition and develop themselves. Women, furthermore, would potentially defend and protect themselves so the high number of discrimination and violence cases against them could decrease in upcoming years.

\section{The Problem that Wadud Would Like to Solve}

Karl Mannheim said about the strong relation between the idea of someone and his/her social background. ${ }^{16}$ As it would be clear later on, there found many things on Wadud's life which really influence on how she thinks about The Qur'an. Wadud was born in Bethesda, Maryland, America, on September 25, 1952, as Maria Teasley. ${ }^{17}$ Since her father was a priest, little Wadud was a Christian. She converted to Islam in 1972 when she was 20. Her interest on Islam, according to her, was mainly based on the Islamic teaching on justice. The day she converted was called, by herself, as the thanksgiving day. ${ }^{18}$ Two years later, she changed the name into Amina Wadud to reconfirm her convertion.

Wadud lived as a part of minority in a religious-social background which is just the same as other Islamic groups in The America. Most of paradigm living in the group is dominated by religious elites who tend to be textualist and the impact affects mostly on women. Discrimination or suppresion against them commonly happen. From such a background, Qur'an and Women was born. This accords to Charles Kurzman who said that the book is actually a response on what Afro-American women experience in struggling the gender justice. ${ }^{19}$ Meanwhile, in the preface of Inside The Gender Jihad,

\footnotetext{
${ }^{16}$ Karl Mannheim, Ideologi dan Utopia, Menyingkap Kaitan Pikiran dan Politik, transl. F. Budi Hardiman (Yogyakarta: Kanisius, 1991), 306.

17 https://en.wikipedia.org/wiki/Amina_Wadud Accessed on June 12, 2017.

18 Amina Wadud, Inside the Gender Jihad, Women's Reform in Islam (England: Oneworld Publications, 2008), 4.

19 For more details, see Charles Kurzman, Wacana Islam Liberal, Pemikiran Islam Kontemporer Tentang Isu-Isu Global, transl. Bahrul Ulum and Heri Junaedi (Jakarta: Paramadina, 2001).
} 
another book of Wadud, Abou el-Fadl mentioned two focus points on Wadud's books on the gender, which are pathriarchial structure and injustice in such society. Wadud, according to him, saw the pathriarcal system as a depotism. It led to negative implication, at minimum, at two extents. First, it eradicates the role of women as the God's trustee (khaliffatullâh). Second, it misses out women's potency as the pious and fatefully creature. ${ }^{20}$

Abou el-Fadl's assumption is reasonable as he experienced the same condition as of Wadud.21 Furthormore, El-Fadl found that some fatwas of SAS (The Society for Adherence to the Sunnah), one of fatwaissuing institutions in the Amerca and CRLO (Council for Scientific Research and Legal Opinions), a legal fatwa issuing institution in the Arab Saudi, are very pathriarcal. This can be seen from the obligation of wife to be obedient in every wordly matter ${ }^{22}$ based on the interpretation of al-Nisâ (4):34. Women are also prohibited to do any public activity to anticipate the fitna. It is based on a hadith narrated by 'Abdullah ibn 'Umar mentioning that it is better for women to pray in her room other than in her house, and it is far better to pray inside the dark cupboard than in the house building. ${ }^{23}$

Through her book, Qur'an and Women, Wadud would like to turn the old exegesis and reconstruct it into an unbiased one. This means a very important implication because the reconstruction possibly keeps the relevance of The Quran on its locus and tempus. Furthermore, it needs to consider that the development of a civilization can be seen from womens' participation number. Those which do not appreciate women position are uncivilized one, such as in Arab Jahiliyah era. From this point, Wadud stated that the understanding on women concept that The Qur'an built 1.400 years ago is really advanced and noble. ${ }^{24}$ However, unfortunately, it was later contamined by the influece of pathriarcal construction.

\footnotetext{
20 Wadud, Inside the Gender Jihad, vii.

21 Khaled M. Abou el-Fadl, Melawan Tentara Tuhan: Yang Berwenang dan Yang Sewenang-wenang, transl. Kurniawan Abdullah (Jakarta: Serambi, 2003), 52-55.

22 Khaled Abou el-Fadl, Atas Nama Tuhan: dari Fikih Otoriter ke Fikih Otoritatif, transl. R. Cecep Lukman Yasin (Jakarta: Serambi, 2004), 303.

${ }^{23}$ Ibn Hajar al-'Asqalânî, Fath al-Bârî, Vol. 2 (Beirût: Dâr al-Fikr, 1993), 227

24 Ibid., xxi.
} 


\section{Method in the Qur'an and Women}

Method here means two things. First is how Wadud elaborated the problem she would like to solve and second is the paradigm she used in reconstructing the exegesis of the Qur'anic verses on gender. Observing the method would possibly expose the paradigmatic frame so this part becomes important to discuss.

It is quite clear that in working on the book, Wadud used descriptive-analytic-critical method. Descriptive means to give clear elaboration on various problems related to women. For example, she explained ambiguity on the word 'women' and to whom it refers to. She mentioned that into this extent, it is important to distinguish between the characteristic and biological thing as in English language, for instance, there found differences between 'sex' and 'gender'. Such classification would later solve any complicated problems related to women as in fact, much culture had still used those two terms improperly. She mentioned that so far, men and women are only viewed solely on biological aspect. As a consequence, nature or characteristic of each gender is ignored through this sexist perspective. The Qur'anic exegesis, in turn, is much influenced by this common mistake and it is where the biased exegesis begins. Above is the summary about what Wadud explored in the preface of her book.

At the first chapter, Wadud argued that basically, men and women are equal. Women are not created from the part (rib) of any men. To support this, she proposed some argument. She then turned to explain the Qur'anic paradigm about women on the second chapter. There she told that the equality between two is clear from the position of women in the hereafter. Moving to the third chapter, she discussed about 'angel' which is commonly assumed as a feminine creature. Later at the last chapter, the fourth one, she elaborated social and domestic implication of the common view to the women's position particularly from the perspective of their right and obligation.

In composing the elaboration, Wadud sought the reference of each theme from all parts of The Qur'an using thematic (maudhu'i) method. After collecting certain verses, she would withdraw the paradigm lines. This method offers an advantage in connecting one verse to others so they could be red holistically and not separated each other. The use of this method is in line with what contemporary 
thinkers like to do in coping with the weakness of classical exegesis. Those exegetical works are considered using myopic method and giving very less explanation on paradigm about certain themes and topics of the Qur'an. They also provide large space to prioritize a certain verse while ignoring other verses talking the same theme. The thematic method lessens the possibility because all of related verses are observed all the way.

Both the themes and verses are critically analyzed on hermeneutic approach. ${ }^{25}$ Hermeneutics is a contemporary paradigm on reading any text which does not only involve things about language, but also ideology, the origin of vocabularies or terms and others. ${ }^{26}$ With no hesitation, Wadud said that she is much influenced by the hermeneutics of Fazlur Rahman. ${ }^{27}$ Rahman argued that The Qur'an is like a summit of floating ice mountain with its $95 \%$ part under the history sea and only $10 \%$ of it is on the surface. ${ }^{28}$ Therefore, to make Islam always relevant to any specific milieu nowadays, Moslems need to deal properly with the traditional and literal Quranic exegesis then turn it into the understanding on the spirit of the Qur'an. It is urgent, at the end, to analyze and find the essence of revelation. ${ }^{29}$

Meanwhile, Wadud built her own hermeneutics on five types of critical analysis. First, questioning in what context a verse was

\footnotetext{
25 Ibid.,. 3.

26 Hermeneutic comes from the Greek word, Hermeneuein, which means giving a meaning, interpreting, translating and playing a role as an interpreter to distinguish between hermeneutic and hermetic. Meanwhile, the word hermetic is a school in philosophy, which associates to hermetic writing; a scientific literature in the Greek that developed in first centuries after Christ and refers to Hermes Trismegistus. See. Alan Lihardson (Ed.), Dictionary of Christian Theology, (London: SCM Press, 1969), 154155; Fahruddin Faiz, Hermeneutika Qur'ani, Antara Teks, Konteks, dan Kontekstualisasi, (Yogyakarta: Qalam, 2003), 16-17.

$27 \mathrm{He}$ is a Pakistan thinker and was born in Septermber, 1919. He named himself as a proponent of Islam neo-modernism. See Abd A'la, Dari Neo Modernisme ke Islam Liberal (Jakarta: Paramadina, 2003), 33.

28 Fazlur Rahman, Metode dan Alternatif Neomodernisme Islam, transl. Taufik Adnan Amal (Bandung: Mizan, 1987), 56. See also, Fazlur Rahman, Islam dan Modernitas tentang Transformasi Intelektual, transl. Ahsin Muhammad (Bandung: Pustaka, 1995), 95.

${ }^{29}$ Ali Masrur, "Ahli Kitab dalam al-Qur'an", in Abdul Mustaqim-Sahiron Syamsuddin (eds.) Studi al-Qur'an Kontemporer (Yogyakarta: Tiara Wacana, 2002), 48.
} 
revealed. Second, observing various topics on the Qur'an. Third, analyzing the diction and syntactic structure of The Qur'an. Fourth, making interpretation based on the Qur'anic principles. Fifth, positioning the Qur'an as the life worldview. ${ }^{30}$ Wadud named those five principles as tauhidi hermeneutics. She does considers 'introductory text' which underlies the activity of interpretation consisting of background, perception and individual condition of a commentator. 31

Wadud used this hermeneutic method as a perspective to reach the ideal role of the Qur'an as the world changer. She mentioned that the Qur'an is the catalyst of any change in spiritual, political, social and intellectual life in Arabian Peninsula. ${ }^{32}$ Unfortunately, she added, "the power of changer" had been stopped by the existence of traditional and reactive exegetical works which, according to her, are exclusive. Mostly, they are written by men and exploring the men's advantages as well as expressing their own interests. 33

\section{Women in the Quran}

The paradigm mentioned above is practically applied in explaining role, position, right and obligation of women as mentioned in the Qur'an. Some of the interpretations are as follow;

\section{In the Origin of Creation, Men and Women are Equal}

Seriously explaining, Wadud wrote some origin problems which make women subordinated. There found some texts from The Qur'an and the hadith which textually indicate that since the origin of creation, women are half-valued of men. It is also believed that they are made by some part of men, particularly the ribs. As a consequence, there found some words of the Qur'an such as "min", "âyah", "zawj", "nafs" and others which are literally interpreted without considering the worldview of the Qur'an. The tendency of this literal meaning could be clearly seen from traditional exegetical

\footnotetext{
30 Amina Wadud, "Qur'an and Women", in Charles Kurzman (ed.), Liberal Islam (New York: Oxford University, 1998), 129.

31 Amina Wadud, Qur'an and Women, 1.

32 Ibid., iv.

33 Ibid., 128.
} 
works such as the book of al-T\{abârî and others. Those works even got much more legitimacy from some tradition or hadith which also look like misogynic. Some of them are hadith(es) about the creation of women from the ribs of men, a pious woman as the world's best ornament, obligation to serve the husbands and so forth.

Quoting al-Nisâ (4): 1 (containing "nafs wâhidah" (a single soul) and "zawjahâ" (her spouse) ${ }^{34}$ and al-Rûm (30): 21 (containing "wa min âyâtihi" (and some parts of His verses), ${ }^{35}$ Wadud questioned why traditional commentators interpreted nafs wâhidah as Prophet Adam, while zawjahâ is Eve. Wadud saw that the origin of problem is on the interpretation of the nafs wâhidah as a lonely human after the very first creation. The interpretation, later, is made relating to another verse, al-Rûm (30): 21, which clearly stated that to overcome the loneliness, Allah gave Adam a company, who is a woman, so he could have fun with her. This impresses that the creation of woman is mainly to satisfy or fulfill the need of a man. For Wadud, the traditional commentators look like uncritical in understanding this passage. In fact, the word nafs refers to female pronoun, but why is it considered referring to Adam, which is a male? ${ }^{36}$

Additionally, Wadud stated that wa min âyâtihi represents a lingustic symbol to confirm God's authority in the unseen world, particularly on the origin of being which can not be logically reached. This matter is certainly different from the visible signs (ayah) such as tress, animals and others which could be fully discovered by ordinary human faculties. The point she stressed is that the God does wants to show anything as the sign of His authority, either from the seen or unseen word. Therefore, the conclusion she drawn is that wa min âyatihi does not refer to the creation of Eve, but to confirm various signs of God's authority, particularly from the unseen one ('alam alghayb). ${ }^{37}$

\footnotetext{
34 "O mankind! Reverence your Guardian Lord, who created you from a single person and creadted of like Nature, his mate".

35 "Among His Signs is that He created for you mates from among yourseleves, that you may dwell in tranquillity with them".

36 Wadud, Qur'an and Women, 17.

37 Ibid., 18.
} 
The word "min", she continued, has two functions of meaning, which are "from", and 'the same nature as'. However, most of traditional commentators such Zamakhsyarî chose the first meaning and consequently, it implies that Eve came from any part of Adam which is considered as the first created being. In the specific case of Zamakhsyarî, Wadud argued that he was much influenced by The Biblical tradition. ${ }^{38}$ Wadud seemed to say that the influence is from some Israiliyyat sources and stories from The Old Testament.

As for the word zawj, Wadud explained that it is a special characteristic for God's pairing creatures. Anything could be named due to the pair coming with. This is just like the saying that there would be no right without left and so do the words men and women. God 'intentionally' creates anything with its own pair or spouse. Adam and Eve, therefore, are a part of the big scenario to create a mutualism symbiois among His creatures. Wadud called this concept as the paradigm of tawhîd. ${ }^{39}$ She explained that the phenomenon of pairs among creatures supports the concept of tawhîd because when all creatures come with their own spouse(s), then the Creator is otherwise. For her, at the end, these verses actually reconfirm the concept of the Oneness of God (tawhîd). ${ }^{40}$

Another point that Wadud emphasized is the belief that Eve was the main cause of explusion of both her and Adam out of the Garden. She began the argument by saying that the word 'tree' actually represents a symbol of divine test for both. In addition to it, prohibition to access the restricted area applied for both and not only for Eve. Both of them also did the same action so they played the same role that caused the explusion. Therefore, she continued, both were obliged to come out of Garden. If only Eve who have had made mistake, the instruction would have had only applied on her.

Wadud also commented on stories telling that at very first, the satan tempted Eve so later on, she could tempt Adam to do the obedience are not from the Qur' an. She then concluded that all by all, the story represents a symbol of fight between humankind and satan. If the human loses, they will suffer damnation and abjection.

\footnotetext{
38 Ibid.

39 Ibid., 26.

40 Ibid.
} 
However, when both Adam and Eve did the real tawbah by repenting and recognizing the mistake while asking for forgiveness, The God forgave them and demonstrated His mercy and grace. This, she continued, is a lesson to learn for all humankind to always do tawbah everytime they make mistakes. ${ }^{41}$

\section{The Concept of Angle}

The Qur'an often talks about the reward at the heaven coming as angels. The word angel itself is the translation of hîur al-'ayni. Surprisingly, said Wadud, many hadiths narrated from the experts of Islamic law interpreted the word as a female pronoun. From this point, according to the traditional exegetical works, women do not only become the second sex and complementer of the men's existence, but also those who sastify sexual desire of heaven (male) occupants. As a consequence, any pious woman would only accompany her husband as the reward of any good deeds.

Regarding with this, Wadud firmly argued that this type of interpretation is unreliable because The Qur'an has not less than ten (10) verses containing some words referring to the angel. Sometimes it uses hîur al-'ayni and sometimes azwâj (plural forms of zawj). ${ }^{42}$ At minimum, said Wadud, there are three facts beyond this concept of angel. First, almost all classical exegetical works described that angels are women. ${ }^{43}$ They serve to satisfy sexual desire of men. This interpretation, according to her, clearly fights against The Qur'an paradigm about justice, equality and pluralism. Second, this gender biased concept is always transformed by traditionalist Moslems to legitimize patriarchal system in various occasion, such as the wedding party and other religious ceremonies (Prophet's birthday, Isra' Mi'raj and others). Third, the concept of angel had become an ideological campaign for certain groups to act radically such as doing a suicide bombing. The cognitive imagination on the angel is transformed into

41 Ibid., 24.

42 Abd al-Bâqi', Muhammad Fuad, Mu'jam al-Mufahrâs li Alfazh al-Qur'ân (Kairo: Dâr al-Fikr, 1992), 280 and 423.

43 See, for example, Abû Ja'far bin Jarîr al-Thabârî, Tafsîr al-Thabârî, Vol. 9, 2nd edition, (Beirut: Dâr al-Salâm, 2007), 7365 and 7836 and Ahmad Shâwî, Tafsîr Shâwî̀, Juz 4,

(Ttp: Dâru Ihyâ' Kutubi al-Arabiyyah, tt), 66. 
the mind of suicide actor as if he would be rewarded by the angel soon after the death. ${ }^{4}$

In fact, as Wadud said, hŷur al-'ayni is the depiction of beutiful women according to the dreams and desires of Arab Jahiliyah. $\underline{H} \hat{u} r$ means fair (skin) while al-'ayni means the eyes, so it comes to a fair skinned and dark eyes woman. Therefore, Wadud said, this sort of historical analysis on where the verses were revealed needs to consider in understanding the verses mentioning the word or its concept. In fact, she continued, verses on the angel actually imply an incentive to aspire after truth. Allah uses the details of Arabic people's common imagination so the message could be easily understood and lead them to convertion.

The concept of angel, on the other hand, is almost same as the concept of heaven with the flowing water beneath the surface. As commonly known, supply of water is the big problem at the desert people so the Qur'an uses the concept to entice Arabians as the first reciever of the Qur'an. Overall, it is clear to Wadud that both concept of paradise and angel are symbols which is actually unreachable by humans' senses. Therefore, God uses the imagination of Arabian people on the thing they are really passionate on.

\section{Distinction between Men and Women}

Wadud admitted that the Qur'an mentions functional distinctions between men and women. Through hermeneutic method focusing on the context of the text, grammatical composition of the text and the whole text, 45 she came into some following insight on the distinction. The first and the foremost is about taqwa which, as told many times in the Qur'an, is the only distinction counts.

Additionally, she argued that women are divinely honored by running the function as 'pro-creator' (al-Nisa, 4: 1) ${ }^{46}$ in continuation process of human existence in the earth through their reproductive system. Wadud saw it as a special gift and reverence from the God. The function of child bearing, she added, is totally not attached to a

\footnotetext{
44 See, for example, Abu Mus'ab, Nasehat-Nasehat Para Ulama untuk Mujahidin, in AlQaedoon Group, www.geocities.com.

45 Ibid., 62.

46 “.... Reverence Allah, through whom you demand your mutual (rights), and (reverence) the wombs that bore you: for Allah ever watches over you".
} 
negative connotation because in addition to it, women could play other roles. She also argued that child bearing is not the primary role for women as commonly thought, because there is no indication in the Qur'an that mothering is women's exclusive roles. Therefore, this role should not restrict them from other roles. ${ }^{4}$

Wadud's argument is reasonable as the child bearing role is often used to weaken the women's position. Javanesse like to describe it with idiom macak (dressing up), masak (cooking) and manak (giving birth) or kasur (bed), dapur (kitchen) and sumur (well). The former describes women's common activities while the latter is three territories of women. Assertively, Wadud mentioned that women are not just biology. They also play a risalah role t8 $^{8}$ just what the men do by participating in public sphere in the realm of prophetic, leadership, justice enforcement, education and so forth.

In relation to this risalah function, Wadud mentioned two related terms, i.e. darajah and faddala, which according to her, indicate value in functional distinction of individuals or groups. Darajah means 'step', 'degree' or 'level'. The search at the whole part of the Qur'an indicates that the word means the result of a real effort which is genderless. This could be clear from al-Nisâ 4:95,49 al-Tawbah 9:20,50 and Thâhâ 20:75.51 The meaning of darajah gives serious implication on the concept of risalah as no matter what role anyone plays, the divine assessment is based on two aspects. First, whether the deeds of risalah is on the basis of taqwa, and second, how the result of the action in running the risâlah role is. ${ }^{22}$ This implies that Wadud does wants to emphasize that there is no normative reason to marginalize women in public sphere because of the gender.

Instead of the matter of gender, the main distinction in running the risalah role is more about knowledge capacity (al-

${ }^{47}$ Ibid., 64.

48 Ibid., 65.

${ }^{49}$ Gaining a higher grade because of fighting and striving in Allah's ways through both soul and body.

${ }^{50}$ Gaining a higher grade because of doing hijrah (moving from one place to another for the sake of Allah).

${ }^{51}$ Gaining a higher grade because of doing good deeds.

52 And in no wise covet those things in which Allah Hath bestowed His gifts more freely on some of you than others: To men is alloted what they earn, and to women what they earn." (QS. al-Nisâ (4): 32). 
Mujâdilah (58): 32), social and economic status (al-Zukhrûf, [43]: 32) and others. To support the argument, Wadud turned to discuess about the content of al-Baqarah (2): 228 which literally says that men have an advantage over women in the case of divorce. For her, this advantage does not apply in any condition. She pointed out that before stating the advantage, The Qur'an mentions some rules about the treatment of $m a^{\prime} r u f$ to women first. $M a^{\prime} r \hat{u} f$ generally means equitable, courteous and beneficial ${ }^{53}$ so the verse should be interpreted in consideration of the rules.

Meanwhile, the latter word, faddala, refers mostly to the God's preference on a type of creation over others, such as the preference of human over other creatures (al-Isrâ' (17): 70), or a prophet over others (al-Baqarah (2): 256). However, this does not mean that The God treats them differently as no distinction exists among them. This, according to Wadud, implies that The God confesses diversity instead of discrimination. In comparison to darajah, faddala is more about gift which means that human only could accept it ${ }^{54}$ and no effort counts. She added, however, that the preference usually requires certain characteristics or attributes attached to the preferred one. This means that if they are not able to take care of the attribute well, the preference is not available anymore.

Regarding to this, Wadud mentioned a verse which, according to her, is often quoted by traditional Islamic groups to legitimize the advantage of men over women. It is al-Nisâ (4): 3455 which literally says the advantage of men over women. Men are said as the leader, protector and care taker over the women as long as they are qualified in two things. First is about the use of their own advantage and the second is economically becoming the breadwinner in a family. However, she stressed that the advantage does not apply unconditionally to all men, as it is confirmed by Qur'anic grammatical structure which uses ba'dluhum meaning some of men. Wadud continued that it only applies to the men with knowledge and managerial skills of leadership.

\footnotetext{
${ }^{53}$ Wadud, Qur'an and Women, 68.

54 Ibid., 69.

55 Men are qawwam (protector) over women because Allah has given the one more (strength) than others, and because their support them (wives) from their means.
} 
Moreover, facts show that some men do not become the breadwinners and the role turns into women who also become the central person in a family both economically and socially. As a consequence, women have the same possibility to become leader, protector and care taker as long as they are qualified in those two aspects. For Wadud, at the end, the chance of men to become qawwâm is also open for women. ${ }^{56}$

\section{Disobedience of Wives}

Literally, al-Nisâ, (4): 34 mentions that a woman who disobeys her husband is allowed to beat. This verse slightly looks as if legitimizing violence on women in a household. However, The Qur'an does not say about finite definition on what disobedience is and in what extent it covers. Some traditional books, such as Uqud alLujain of Nawawi Banten, mentioned that the wife's obedience applies in most of condition, including performing non-compulsory fasting and visit to parents who have just passed away which could be legal on husband's permission. It is even said that for wives, any noncompulsory worship must not be prioritized over sexual services.

Relating to this, Wadud questioned on why the case of disobedience only applies for wife. She wondered considering that the chance of disobedience could come from both parties. To support the argument, he quoted al-Nisâ' (4): 128 explaining that a husband could also do disobedience by having dull characteristics in treating his wife and not fulfilling her right. Therefore, Wadud continued, al-Nisâ' (4): 34 actually talks about the disruption on family harmony ${ }^{57}$ and as a consequence, any physical strike or chastismenet is not the best solution to overcome the condition.

To cope with the condition of disharmony, Wadud thought that The Qur'an teaches a variety of ways on this following priority scale. First is through the verbal resolution. It could happen between the two parties as told in al-Nisâ' (4): 34 or by involving a third person as the arbiter as in al-Nisâ' (4):28. Second is through separation or having beds apart. If this does not work as well, then it comes to the third alternative, physical strike or hit, which she mentioned as the

\footnotetext{
56 Ibid., 71.

57 Ibid., 75.
} 
most extreme way. ${ }^{58}$ Among the three, Wadud pointed out the the best one is the first as it is in line to the principle of syura as told in alNisâ' (4): 128.

Furthermore, the word 'dlaraba' on al-Nisâ' (4):34, she continued, does not always mean to hit or to strike. Quoting explanation from Lisân al-'Arab, she said that the word has another meaning which is 'giving or setting the example'. According to her, this later meaning automatically eliminates the physical violence practice in the conflict resolution ${ }^{59}$ and consequently, the former meaning could not be used anymore. Moreover, it contradicts to the Qur'anic idea about prohibition on violence and equality between men and women. The concept of nusyuz, she concluded, is really casuistic and contextual. She went on by mentioning following related questions: On what aspect is the obedience needed? Does the wife's obedience accords to the treatment of her husband? What type of husband that a wife must obey to? What if the husband does any disobedience? Is the argument of permission for beating has historic root and be well researched?

In the last chapter of the book, Wadud discussed much about social reformation spirit of the Qur'an relating to the position of women. She clearly stated that the effort never finishes and still continues till today. It began from the era of Mohammad and goes on nowadays. She elaborated some patriarchal biased problems such as polygamy, divorce, child care and others. It all impresses that Wadud declared herself as a part of those successors of Islamic reform. Certainly, she is not alone as many contemporary intellectuals share the same opinion as well as methodology as hers.

\section{Closing (Conclution and Reflection)}

From the above passages, it could be concluded that in short, Amina Wadud criticized gender biased exegetical works on the Qur'an using two steps. The first is by examining on how The Qur'an mentions some relating issues using the method of descriptiveanalytical-and critical one. She described the problem on women, analyzed some related verses through thematic method and criticized

\footnotetext{
58 Ibid.

59 Ibid., 76
} 
existing exegetical works through hermeneutic paradigm. The second is by creating generalization on special respons about historical background then mention it as the social moral aspect. In addition to specific responses on some verses, Wadud also made generalization by considering the ratio logic.

Wadud came to a conclution that in a pathriarcal and conservative relgious society, women are only considered as the second class layer. They are trapped in the domestic sphere and do household things such as what centered in well, bed and kitchen. However, she continued, the history has turned out into the second layer as at nowadays social structure, it is not hard to find woman with advantages and expertise that they can compete right away. In other word, being a woman does not give an obstacle anymore to be a career person as well as a leader (qawwam or playing qiwamah role). The remaining question is all about how big is the women's endurence in career and leadership contestation which put big appreciation on quality and professionalism?

To assure that women could fairly compete in the contestation, there are at least two changes to do, which are internal and external. For the former one, women need to change their self awareness and build the critical thinking. More or less, critical thinking means the awareness that anything happens for a certain interest of specific persons or structure. It does not only deal with social realm, but also on reading exegetical works. In dealing with exegetical works, this would return the Holy Book to its primordial mission.

Meanwhile on the external aspect, it needs to make a change on a gender-biased structure. At very first, this could be done by deconstructing pathriarcal mind in a community or social group through seminar, religious forum, or other meetings. The aim is to create a balanced mindset about the leadership of men and women as well puting consideration on quality and professionalims above the difference of sex.

The next step is a change or betterment in the policy realm from both the substance and the mechanism. On the substance, it needs to create a fair policy for both sexes while on mechanism, there should be balanced and fair participation of both two in policy making process. 


\section{Bibliography}

Andiani, Asna. "Konsep Penciptaan Perempuan: Studi Atas Pemikiran Amina Wadud dalam Buku Qur'an And Woman" Kontemplasi, Vol. 01 No. 02 (November 2013).

al-'Asqalânî, Ibn Hajar. 1993. Fath̆u al-Bârî, Vol. 2. Beirut: Dâr al-Fikr.

A'la, Abd. 2003. Dari Neo Modernisme ke Islam Liberal. Jakarta: Paramadina.

Baz, Ibn. 1988. Majmû' al-Fatâwâ, Vol. 1. Beirût: Dâr al-Qalâm.

al-Bâqi', Muhammad Fuâd 'Abd. 1992. Mu'jamu al-Mufahrâs li Alfâzhi al-Qur'âłn. Kairo: Dâr al-Fikr.

Dewi, Ernita. "Pemikiran Amina Wadud tentang Rekonstruksi Penafsiran BerbasisMetode Hermeneutik". Substantia, Vol. 15, No. 2 (October 2013).

Engineer, Asghar Ali. 1992. The Right of Women in Islam. Lahore: Vanguard Books (PVT) LTD.

el-Fadl, Khaled Abou. 2004. Atas Nama Tuhan.Jakarta: Serambi, Yang Sewenang-wenang, transl. Kurniawan Abdullah. Jakarta: Serambi, 2003.

Fakih, Mansour (dkk). 2000. Membincang Feminisme, Diskursus Gender dalam Perspektif Islam. Surabaya: Risalah Gusti.

Irsyadunnas. "Tafsir Ayat-Ayat Gender Ala Amina Wadud Perspektif Hermeneutika Gadamer". Musâwa, Vol. 14, No. 2 (Juli, 2015).

Kurzman, Charles (ed.). 1998. Liberal Islam. New York: Oxford University.

--_ 2001. Wacana Islam Liberal, Pemikiran Islam Kontemporer Tentang Isu-Isu Global, transl. Bahrul Ulum and Heri Junaedi. Jakarta: Paramadina.

Lihardson, Alan (Ed.). 1969. Dictionary of Christian Theology. London: SCM Press.

Mannheim, Karl. 1991. Ideologi dan Utopia, Menyingkap Kaitan Pikiran dan Politik, transl. F. Budi Hardiman. Yogyakarta: Kanisius, 1991.

Mustaqim, Abdul dan Sahiron Syamsuddin (eds.). 2002. Studi alQur'an Kontemporer. Yogyakarta: Tiara Wacana. 
Mutrofin. "Kesetaraan Gender dalam Pandangan Amina Wadud dan Riffat Hasan". Teosofi: Jurnal Tasawuf dan Pemikiran Islam, Vol. 3 No. 1 (June 2013).

Nasr, Sayyed Hossein. 1967. Islamic Studies: Essay on Law and Society. Beirut: Libreirie Du Liban.

Nuryanto, M. Agus. 2001. Islam, Teologi Pembebasan dan Kesetaraan Gender: Studi atas Pemikiran Asghar Ali Engineer. Yogyakarta: UII Press.

Rahman, Fazlur. 1995. Islam dan Modernitas tentang Transformasi Intelektual. Bandung: Pustaka.

-_-_-_ 1987. Metode dan Alternatif Neomodernisme Islam. Bandung: Mizan.

Saenong, Ilham B. 2002. Hermeneutika Pembebasan: Metodologi Tafsir alQur'an Menurut Hasan Hanafi. Jakarta: Teraju, 2002.

Saidah, Nor. "Bidadari dalam Konstruksi Tafsir al-Qur'an: Analisis Gender atas Pemikiran Amina Wadud Muhsin dalam Penafsiran al-Qur'an". PALASTREN, Vol. 6, No. 2 (Desember 2013).

Shâwî, Ahmad. Tafsîr Shâwî̀, Vol. 4. Ttp: Dâru Ihyâ' Kutubi alArabiyyah, tt.

Soleh, A.Khudori. 2003. Pemikiran Islam Kontemporer. Yogyakarta: Jendela, 2003.

Syahrûr, Muhammad. 1990. Dirâsât Islâmiyah Mu'ashirah, Nahrwa Ushûl al-Jadîdah li al-Fiqh al-Islâmî. Damaskus: al-Ahâli.

al-Thabârî, Abû Ja'far bin Jarîr. 2007. Tafsîr al-Thabârî, Vol. 9, Vol. II. Beirût: Dâr al-Salâm.

Tim Risalah Gusti (ed.). 2000. Membincang Feminisme; Diskursus Gender Perspektif Gender. Surabaya: Risalah Gusti.

Wadud Muhsin, Amina. 2008. Inside the Gender Jihad, Women's Reform in Islam. England: Oneworld Publications, 2008.

Bakti Sdn Bdn, 1994.

Zayd, Nasr Hamd Abu. 2004. Dawâir al-Khawf: Qirâatu 'alâ Khitâbi alMar'ah, Vol. III. Beirut: Dâr al-Baidla'. 